Volume 9. Nomor 1. Januari 2014
Pandecta
http://journal.unnes.ac.id/nju/index.php/pandecta

\title{
Urgensi Pengaturan Khusus Lisensi Paten tentang Alih Teknologi pada Perusahaan Joint Venture
}

\author{
Ana Nisa Fitriati ${ }^{\bowtie}$ \\ Fakultas Hukum, Universitas Negeri Semarang, Indonesia \\ Permalink/DOI http://dx.doi.org/10.15294/pandecta.v9i1.2998
}

\begin{tabular}{l} 
Info Artikel \\
\hline Sejarah Artikel: \\
Diterima Oktober 2013 \\
Disetujui November 2013 \\
Dipublikasikan Januari 2014 \\
\hline Keywords: \\
transfer of technology; joint \\
venture; patent licensing; \\
political will
\end{tabular}

\begin{abstract}
Abstrak
Alih teknologi melalui perjanjian lisensi paten di Indonesia masih belum terlaksana secara optimal, oleh karenanya penelitian ini diadakan untuk mengetahui pelaksanaan pengaturan lisensi paten dan urgensi pengaturan khusus lisensi paten di bidang alih teknologi pada perusahaan joint venture. Jenis penelitian yang digunakan adalah yuridis empiris, dengan menggabungkan peraturan perundang-undangan, kajian pustaka dan pendapat responden serta informan melalui wawancara. Hasil penelitian didapatkan bahwa Pemerintah telah mengatur alih teknologi pada Undang-Undang No. 14 Tahun 2001 tentang Paten; Undang-Undang No. 25 Tahun 2007 tentang Penanaman Modal; dan Undang-Undang No. 3 Tahun 2014 tentang Perindustrian. Pelaksanaan pengaturan lisensi paten pada alih teknologi masih terkendala belum adanya Peraturan Pemerintah yang telah diamanatkan dalam Pasal 73 Undang-Undang No. 14 Tahun 2001 tentang Paten. Terlaksananya alih teknologi sangat dipengaruhi oleh peraturan perundang-undangan yang dimiliki oleh negara tersebut, sehingga budaya hukum dan struktur hukum tidak dapat terwujud apabila substansi hukum alih teknologinya belum ada. Simpulan yang didapat adalah pengaturan lisensi paten pada alih teknologi masih terkendala belum diundangkannya Peraturan Pemerintah tentang Lisensi Paten karena berkaitan dengan political will dari Pemerintah dan sangat urgen untuk segera mengundangkan Draf Rancangan Peraturan Pemerintah tentang Lisensi Paten dan Lisensi Wajib menjadi Peraturan Pemerintah tentang Lisensi Paten dan Lisensi Wajib.
\end{abstract}

\begin{abstract}
Transfer of technology through patent license agreements in Indonesia is still not optimally implemented, this study therefore conducted to determine the implementation of patent licensing arrangements and urgency special patent license arrangements in the field transfer of technology to the joint venture company. This type of research is empirical jurisdiction, by combining legislation, literature and opinions of respondents and informants through interviews. The results showed that the Government had set up transfer of technology to the Act No. 14 of 2001 on Patents; Act No. 25 of 2007 on Investment; and Act No. 3 of 2014 on Industry. Implementation of patent licensing arrangements on transfer of technology is still constrained absence of government regulation that has been mandated in Article 73 of Act No. 14 of 2001 on Patents. Implementation transfer of technology is strongly influenced by the legislation which is owned by the state, so that legal culture and legal structure can not be achieved if the technology is not yet legal substance over there. The conclusions is obtained patent licensing arrangements on transfer of technology is still constrained yet enacted Government Regulation of Patent License as it pertains to the political will of Government and very urgent to immediately enact Draft Regulation on Compulsory Patent Licensing and Licensing be Government Regulation on Compulsory Patent Licensing and Licensing.
\end{abstract}




\section{Pendahuluan}

Negara-negara berkembang seperti Indonesia dalam ketersediaan modal untuk melaksanakan pembangunan nasional di sektor ekonomi, mengalami banyak kesulitan. Menurut Ilmar (2006), kesulitan-kesulitan tersebut disebabkan oleh berbagai faktor misalnya tingkat tabungan (saving) masyarakat yang masih rendah, akumulasi modal yang belum efektif dan efisien, keterampilan (skill) yang belum memadai serta tingkat teknologi yang juga belum maju. Guna mengatasi kesulitankesulitan tersebut, berbagai macam cara dilakukan oleh pemerintah Indonesia untuk memenuhi kekurangan modal dalam negeri di antaranya dengan membuka penanaman modal khususnya Penanaman Modal Asing (PMA) secara besar-besaran.

Bentuk investasi melalui PMA ini kemudian diatur lebih jelas dalam Pasal 1 ayat (3) Undang-Undang Nomor 25 Tahun 2007 tentang Penanaman Modal yaitu investasi secara langsung (100\% asing) dan secara usaha patungan (joint venture). Sumantoro (1984) menyatakan bahwa peran ideal dari adanya suatu kegiatan penanaman modal asing pada prinsipnya didasari oleh harapan akan terjadinya transfer of capital, transfer of technology dan transfer of management. Transfer of technology dimaksudkan agar bangsa Indonesia menjadi bangsa yang mandiri dan tidak selalu bergantung dengan pihak asing, namun untuk menunjangnya diperlukan adanya suatu perjanjian lisensi.

Lisensi paten merupakan suatu bentuk izin yang diberikan oleh pemegang paten kepada penerima paten berdasarkan perjanjian pemberian hak untuk melakukan serangkaian tindakan atau perbuatan untuk menikmati manfaat ekonomi dari suatu paten yang diberikan kepadanya dengan perlindungan selama jangka waktu dan syarat tertentu. Dasar hukum pengaturan perjanjian lisensi paten terdapat di dalam Pasal 69-73 Undang-Undang No.14 Tahun 2001 tentang Paten. Tidak hanya itu, perjanjian lisensi didasarkan pula pada asas-asas dalam hukum kontrak seperti pertama asas kebebasan berkontrak yang termuat dalam Pasal 1338 ayat (1) KUH Perdata; kedua asas konsensualisme yang dia- tur dalam Pasal 1320 ayat (1) KUH Perdata; ketiga asas pacta sunt servanda yang termuat dalam Pasal 1338 ayat (1) KUH Perdata; dan terakhir asas itikad baik adalah Pasal 1338 ayat (3) dan Pasal 1339 KUH Perdata.

Sebagaimana tujuan Penanaman Modal Asing yakni untuk mempercepat alih teknologi, sebagai regulator, pemerintah telah menyiapkan regulasi-regulasi yang dibutuhkan guna menunjang alih teknologi dan lisensi paten. Setidaknya terdapat 3 (tiga) undang-undang yang dominan mengaturnya antara lain pertama, Undang-Undang No. 14 Tahun 2001 tentang Paten; kedua, UndangUndang 25 Tahun 2007 tentang Penanaman Modal; dan ketiga, Undang-Undang No. 3 Tahun 2014 tentang Perindustrian. Meskipun undang-undang telah mengatur sedemikian rupa, namun Hartono (1972) mengungkapkan bahwa dalam pelaksanaan lisensi paten ditemui beberapa hambatan sehingga walaupun lisensi-lisensi paten telah berlangsung, tetapi tidaklah dapat membantu bangsa Indonesia dalam rangka pengalihan teknologi. Salah satu yang menjadi hambatannya adalah tidak adanya pengawasan perjanjian lisensi karena perjanjian tersebut tidak pernah terdaftar dan tidak adanya pembatasan jangka waktu terhadap perjanjian lisensi paten tersebut.

Hambatan-hambatan dalam rangka pengalihan teknologi erat kaitannya dengan sistem hukum Hak Kekayaan Intelektual yang dimiliki oleh negara tersebut. Friedman mengungkapkan bahwa berhasil atau tidaknya suatu sistem hukum bergantung pada struktur hukum, substansi hukum, dan budaya hukum. Unsur pertama, struktur hukum atau legal structure merupakan institusionaliasi ke dalam entitas-entitas hukum yang berkaitan dengan aparatur pelaksana dan penegakkan hukumnya. Friedman menegaskan bahwa hukum memiliki elemen pertama dari sistem hukum berupa struktur hukum, tatanan kelembagaan, dan kinerja lembaga (Suherman 2004).

Unsur kedua, substansi hukum atau legal substance merupakan aturan, norma, dan pola perilaku manusia yang berada dalam sistem (Suherman 2004). Unsur ketiga, budaya hukum atau legal culture yang menurut 
Friedman adalah sikap manusia terhadap hukum dan sistem hukum, kepercayaan, nilai, pemikiran, serta harapannya. Teori Friedman mengenai sistem hukum, dapat dijadikan sebagai patokan dalam mengukur proses pelaksanaan pengaturan lisensi paten di bidang alih teknologi. Berhasilnya sistem hukum Hak Kekayaan Intelektual, dapat menentukan fungsi hukum Hak Kekayaan Intelektual di Indonesia nantinya.

\section{Metode Penelitian}

Jenis penelitian yang digunakan adalah yuridis empiris. Pendekatan yuridis digunakan untuk menganalisis berbagai peraturan perundang-undangan. Sedangkan pendekatan empiris digunakan untuk menganalisis hukum yang dilihat sebagai perilaku masyarakat yang berpola dalam kehidupan masyarakat yang selalu berinteraksi dan berhubungan dalam aspek kemasyarakatan. Data yang digunakan dalam penelitian ini terdiri atas data primer dan data sekunder (Soekanto 1998). Data primer diperoleh dari studi lapangan dengan cara wawancara di Direktorat Jenderal Hak Kekayaan Intelektual, Badan Koordinasi Penanaman Modal dan responden di Kementerian Riset dan Teknologi Republik Indonesia. Sedangkan data sekunder diperoleh dari studi kepustakaan berupa peraturan perundang-undangan, penelitian terdahulu dan buku-buku ilmiah tentang pelaksanaan lisensi paten alih teknologi pada perusahaan joint venture. Metode analisis data yang sesu- ai dengan penelitian ini adalah pendekatan secara kualitatif, yaitu analisis data dengan cara mengungkapkan dan mengambil kebenaran yang diperoleh dari data primer dan data sekunder, sehingga mendapatkan suatu pemecahannya dan selanjutnya dapat ditarik kesimpulan.

\section{Hasil dan Pembahasan}

\section{a. Pelaksanaan Pengaturan Lisensi Paten Alih Teknologi pada Perusahaan Joint Venture}

Implementasi perlindungan paten di Indonesia yang telah diamanatkan di dalam Undang-Undang No. 14 Tahun 2001 tentang Paten, pada praktiknya ternyata masih belum secara maksimal dimanfaatkan oleh masyarakat. Hal ini menjadi relevan ketika melihat data yang disajikan dalam tabel jumlah pemohon paten di Indonesia yang dibuat oleh Direktorat Jenderal Hak Kekayaan Intelektual pada Tabel 1.

Data pada Tabel 1 menunjukkan bahwa masih rendahnya jumlah permohonan paten Indonesia jika dibandingkan dengan negara-negara tetangga seperti negara Malaysia, Singapura bahkan Cina. Tidak hanya itu, pemohon paten di Indonesia juga lebih didominasi oleh pemohon paten yang berasal dari luar negeri. Pada data tersebut memang terlihat bahwa jumlah permohonan untuk paten sederhana yang didaftarkan oleh inventor Indonesia lebih banyak jika dibandingkan dengan paten biasa yang didaftarkan

Tabel 1. Data Permohonan Paten Tahun 2009-2011

\begin{tabular}{|c|c|c|c|c|c|c|c|c|c|c|}
\hline \multirow{2}{*}{ No. } & \multirow{2}{*}{ Negara } & \multicolumn{3}{|c|}{2009} & \multicolumn{3}{|c|}{2010} & \multicolumn{3}{|c|}{2011} \\
\hline & & Lokal & Asing & Jumlah & Lokal & Asing & Jumlah & Lokal & Asing & Jumlah \\
\hline 1. & Cina & 877611 & 99075 & 976686 & 293066 & 98111 & 391177 & 467120 & 905788 & 2372908 \\
\hline 2. & Thailand & 4196 & 5534 & 9730 & 3539 & 2000 & 5539 & 2728 & 2077 & 4805 \\
\hline 3. & Malaysia & 1234 & 4503 & 5737 & 1275 & 5189 & 6464 & 1136 & 5423 & 6559 \\
\hline 4. & Singapura & 827 & 7909 & 8736 & 892 & 8881 & 9773 & 1056 & 8738 & 9794 \\
\hline 5. & Indonesia & 684 & 4145 & 4829 & 795 & 5485 & 6280 & 777 & 5353 & 6130 \\
\hline 6. & Filipina & 22 & 1657 & 1679 & 13 & 1140 & 1153 & 6 & 1129 & 1135 \\
\hline
\end{tabular}

Sumber : Naskah Akademik Rancangan Undang-Undang tentang Paten atas Perubahan Undang-Undang No. 14 Tahun 2001 tentang Paten 
oleh inventor Indonesia, namun secara keseluruhan jumlahnya masih minoritas jika dibandingkan dengan paten yang berasal dari luar negeri. Kondisi paten Indonesia ini erat kaitannya dengan praktik penyelenggaraan penerapan undang-undang paten, seperti :

\section{Kendala teknis prosedural.}

Pertama, jangka waktu pengurusan paten hingga memperoleh sertifikat paten di Indonesia diatur dalam Pasal 54 Undang-Undang No. 14 Tahun 2001 tentang Paten, namun pada praktiknya, untuk mengajukan permohonan paten relatif lama yakni bisa mencapai 5-8 (lima sampai delapan) tahun, hal ini disebabkan oleh adanya proses-proses verifikasi ilmiah. Kedua, biaya pengurusan paten yang terdiri atas biaya permohonan dan pemeliharaan paten di Indonesia yang relatif mahal. Besarnya biaya tersebut jelas memberatkan bagi peneliti atau para inventor Indonesia yang pada umumnya bukanlah para pengusaha besar, apalagi jika paten yang didaftarkan ternyata tidak memiliki nilai komersial sama sekali. Ketiga, prosedur pendaftaran paten yang mewajibkan bagi para inventor untuk datang langsung ke Direktorat Jenderal Hak Kekayaan Intelektual padahal Indonesia merupakan negara kepulauan, jarak antara satu pulau dengan pulau lainnya tentu memakan waktu dan biaya yang tidaklah sedikit.

\section{2, Kendala budaya masyarakat}

Pertama, setiap kali diadakan lomba maupun pameran yang berkaitan dengan teknologi, peserta (inventor) dan panitia penyelenggaranya belum mengaitkan dengan perlindungan hukumnya yang telah diatur melalui Undang-Undang No. 14 Tahun 2001 tentang Paten. Kedua, Maulana (1996) mengatakan bahwa selama ini telah banyak pemuda Indonesia yang dikirim dan dibiayai oleh negara untuk melanjutkan tugas belajarnya di luar negeri khususnya di negara-negara maju, namun sangat disayangkan tidak banyak yang mampu membawa pulang invensi mereka yang bermanfaat bagi negara.
Padahal penemuan yang mereka lakukan berhak atas paten dan berhak memperoleh perlindungan hukum serta berhak pula atas royalti apabila pihak lain menggunakannya.

Ketiga, Badan Pembinaan Hukum Nasional (BPHN) mencatat dalam Naskah Akademik Rancangan Undang-Undang Paten atas Perubahan Undang-Undang No. 14 Tahun 2001 tentang Paten bahwa muncul adanya kekhawatiran di pihak para investor jika memakai teknologi lokal yang telah dipatenkan untuk usaha mereka ternyata gagal, maka tidak ada yang bertanggungjawab atas kegagalan tersebut yang pada akhirnya menimbulkan kerugian di pihak investor.

Keempat, belum banyak institusi pendidikan yang memahami akan pentingnya perlindungan paten. Indonesia memiliki 3702 (tiga ribu tujuh ratus dua) perguruan tinggi, yang terdiri atas universitas, institut, sekolah tinggi, akademi, dan politeknik baik negeri maupun swasta (Tampubolon 2013), namun hasil karya yang berupa riset yang dihasilkan mereka masih belum banyak yang didaftarkan pada Direktorat Paten. Alasannya, keengganan dari para inventor untuk mendaftarkan invensinya karena tidak adanya penghargaan atau reward bagi para peneliti tersebut yang telah berhasil menghasilkan suatu invensi sehingga semangat untuk terus melakukan penelitian guna menghasilkan invensi pun menjadi menurun.

Melihat kondisi paten dan praktik penyelenggaraannya, sejauh ini pemerintah telah melakukan beberapa upaya untuk meningkatkan jumlah permohonan paten Indonesia. Pertama, pemerintah kerap melakukan sosialisasi ke berbagai pihak seperti Usaha Mikro Kecil Menengah (UMKM), Perguruan Tinggi baik negeri maupun swasta, serta masyarakat umum yang berkepentingan dengan Hak Kekayaan Intelektual dengan memberikan pemahaman agar tumbuh kesadaran akan perlindungan Hak Kekayaan Intelektual terutama patennya. Selain itu, pemerintah juga telah mengadakan kerjasama dengan instansi terkait yang bertujuan untuk membangun sentra-sentra Hak Kekayaan Intelektual yang tentunya dengan harapan dapat membantu mensosialisasikan pemanfaatan perlindungan 
paten tersebut.

Kedua, dewasa ini pemerintah juga mulai memberikan suatu insentif baik berupa penghargaan, reward atau beasiswa kepada lembaga-lembaga penelitian, perguruan tinggi, pelaku usaha yang mampu menghasilkan invensi yang dapat dipatenkan dengan tujuan agar para peneliti tetap semangat untuk terus melakukan penelitian-penelitian dan menghasilkan invensi yang bermanfaat dan dapat dipatenkan nantinya. Dengan demikian diharapkan jumlah pemohon paten dalam negeri menjadi meningkat.

Ketiga, mengatasi kekhawatiran para investor untuk memakai teknologi lokal yang dipatenkan, pemerintah memberikan jaminan sebagai bentuk penjaminan resiko usaha atas kegagalan teknologi lokal yang dipatenkan tersebut, hal ini sesuai dengan yang telah diamanatkan dalam Pasal 40 Undang-Undang No. 3 Tahun 2014 tentang Perindustrian. Dengan demikian, maka para investor akan memakai teknologi lokal yang telah dipatenkan, dan dengan keinginan investor inilah yang nantinya akan menumbuhkan kesadaran para inventor nasional untuk mau mendaftarkan invensinya.

\section{b. Alih Teknologi pada Penanaman Modal Asing (Joint Venture)}

Pemerintah Indonesia menyadari bahwa teknologi merupakan salah satu bagian yang dibawa oleh pihak asing ke Indonesia melalui kegiatan penanaman modal asing, seperti yang terumus di dalam Pasal 2 sub b Undang-Undang No. 1 Tahun 1967 tentang Penanaman Modal Asing dimana teknologi diartikan sebagai alat-alat untuk perusahaan, termasuk penemuan-penemuan baru milik orang asing dan bahan-bahan yang dimasukkan dari luar ke dalam wilayah Indonesia, selama alat-alat tersebut tidak dibiayai dari kekayaan devisa Indonesia.

Pemahaman mengenai alih teknologi pada umumnya dimaknai sebagai pengalihan kemampuan teknologi yang dipunyai oleh negara-negara maju kepada negaranegara berkembang. Konsep alih teknologi dalam perkembangannya ternyata tidak lagi dipersepsikan sebagai pengalihan teknologi dari negara maju kepada negara berkembang saja, namun dapat pula terjadi antara licensor dan licensee yang sama-sama berada di dalam negeri. Pasal 1 ayat (11) Undang-Undang No. 18 Tahun 2002 tentang Sistem Nasional Penelitian, Pengembangan, dan Penerapan Ilmu Pengetahuan dan Teknologi menegaskan bahwa alih teknologi adalah pengalihan kemampuan memanfaatkan dan menguasai ilmu pengetahuan dan teknologi antar lembaga, badan, atau orang, baik yang berada di lingkungan dalam negeri maupun yang berasal dari lingkungan luar negeri ke dalam negeri dan sebaliknya. Sehingga para pihak dalam proses alih teknologi dapat berasal dari dalam dan luar negeri atau sebaliknya.

Alih teknologi merupakan salah satu upaya yang dilakukan oleh negara berkembang untuk mengurangi ketergantungannya kepada negara maju. Namun dalam perkembangannya, hal ini dapat menimbulkan ketergantungan teknologi pada negara berkembang terhadap negara maju. Tampubolon (2013) juga menambahkan bahwa ketergantungan teknologi dapat terjadi jika sumbersumber utama teknologi yang terdapat di negara-negara berkembang berasal dari luar negeri.

Oleh karenanya, alih teknologi dari negara maju kepada negara berkembang boleh saja dilakukan untuk meningkatkan kemakmuran negara berkembang, meskipun dalam prosesnya tidaklah semudah yang dibayangkan. Hal ini ditegaskan oleh Purba (2011) bahwa teknologi memang harus direbut atau dalam ungkapan yang lebih langsung adalah 'dicuri'. Itulah sebabnya, Jepang pernah menggegerkan dunia internasional dengan resep penguasaan teknologi (Folsom dalam Purba 2011). Namun dasar yang menumbuhkan perlakuan curi ini menurut Purba (2011) terdapat dua hal yaitu :

1. Bahwa pemilik teknologi tidak akan rela memberikan barang yang dimilikinya, betapapun aspek komersial mengkerangkai transaksi peralihan itu, paling-paling yang dilakukan adalah pemberian teknologi seadanya;

2. Pencuri dapat berdalih bahwa misi besar di belakang ini adalah juga untuk kemajuan umat manusia.

Pendapat Purba tentu ada benarnya, 
karena pada saat penerima teknologi menerima teknologi dari pemegang teknologi melalui suatu perjanjian lisensi, tentunya teknologi yang diberikan kepada penerima teknologi telah menjadi teknologi yang ketinggalan, karena di saat itulah pemegang teknologi sudah memiliki teknologi baru yang jauh lebih baik lagi. Hal serupa juga dapat dilihat melalui keterkaitan antara masa berlaku perlindungan paten dan lisensi patennya, sudah bukan menjadi rahasia lagi jika inventor biasanya akan mengembangkan teknologi yang ada sehingga ditemukan invensi yang baru yang kemudian akan dipatenkan kembali, sedangkan paten sebelumnya tidak bisa diperpanjang lagi jangka waktunya. Ketertinggalan teknologi seperti ini akan terus berlanjut dengan pola yang sama, mengingat aspek komersial dalam suatu invensi yang dipatenkan.

Sehingga, alangkah baiknya jika alih teknologi dari negara maju tersebut juga dibarengi dengan alih teknologi yang para pihaknya sama-sama berada di dalam negeri, dengan tujuan memajukan ilmu pengetahuan dan teknologi di dalam negeri sendiri guna mengoptimalkan kemandirian perekonomian nasional negara berkembang.

\section{c. Hambatan-Hambatan Pelaksanaan Alih Teknologi dalam Kaitan Pengaturan Lisensi Paten}

Berdasarkan penelitian yang dilakukan, pada dasarnya pengaturan kontrak lisensi paten yang tertuang pada Pasal 69-73 Undang-Undang No. 14 Tahun 2001 tentang Paten tidaklah bersifat sumir. Pertama, perlindungan lisensi paten sepanjang yang diatur oleh Pasal 69 Undang-Undang No. 14 Tahun 2001 tentang Paten adalah dengan melihat jangka waktu perlindungan jenis patennya dan tidak boleh melebihi jangka waktu perlindungan patennya. Berkaitan antara jangka waktu perlindungan paten yakni selama 20 (dua puluh) tahun dengan jangka waktu yang diberikan oleh negara bagi perusahaan joint venture untuk berkegiatan di Indonesia yakni selama 30 (tiga puluh) tahun, maka terdapat sisa jangka waktu 10 (sepuluh) tahun bagi perusahaan joint venture tersebut untuk berkegiatan di Indonesia. Teknologi pada perusahaan joint venture selama 10 (sepuluh) tahun tersebut pada akhirnya akan menjadi public domain, dengan kata lain teknologi pada perusahaan joint venture akan bebas digunakan oleh siapa saja tanpa harus meminta ijin kepada inventornya.

Kedua, ruang lingkup dan pengertian pembatasan-pembatasan atau hambatanhambatan dalam perjanjian lisensi paten yang tidak diizinkan adalah jika merugikan perekonomian negara yang dimaksudkan dalam Pasal 71 Undang-Undang No. 14 Tahun 2001 tentang Paten, sebagai contoh adalah dalam hal penyediaan bahan baku selama bahan baku tersebut masih terdapat dan dapat terpenuhi di wilayah Indonesia maka tidak boleh mengimpor bahan baku dari luar negeri. Tidak hanya itu, hasil produksi yang tidak diekspor atau dengan kata lain hasil produksi tersebut tidak dapat menggantikan barang-barang impor dan mengirimkan semua keuntungan yang diperoleh mereka kepada perusahaan induk di luar negeri, turut menjadi faktor yang dapat merugikan perekonomian negara pula.

Ketiga, Pasal 72 Undang-Undang No. 14 Tahun 2001 tentang Paten menegaskan bahwa perjanjian lisensi paten wajib dicatatkan pada Direktorat Jenderal. Tidak terdaftarnya perjanjian lisensi paten tersebut tentunya bagi para pelaku usaha tidak menimbulkan akibat hukum terhadap pihak ketiga, namun selama tahun 2001 hingga tahun 2013, Direktorat Jenderal belum melakukan pencatatan terhadap perjanjian lisensi paten. Hal ini disebabkan pengaturan lebih detail terkait pencatatan lisensi paten seperti bentuk formulir, biaya pendaftaran, dan persyaratannya masih belum ada, namun pemerintah mulai menyusun draf Peraturan Pemerintah tentang lisensi paten dan lisensi wajib. Draf Peraturan Pemerintah menyebutkan bahwa ketentuan lebih lanjut mengenai bentuk dan isi formulir permohonan pencatatan perjanjian lisensi akan diatur lebih lanjut dengan Peraturan Menteri, sehingga agaknya landasan hukum mengenai pencatatan perjanjian lisensi paten akan menjadi lebih lama lagi untuk diterapkan, padahal pencatatan lisensi paten sangat segera dibutuhkan agar alih teknologi benarbenar terwujud dan tidak ada ketentuan-ketentuan dalam perjanjian lisensi paten yang 
dapat merugikan perekonomian nasional.

Selain itu, perbedaan pemaknaan cara alih teknologi antara Badan Koordinasi Penanaman Modal dan Direktorat Jenderal Hak Kekayaan Intelektual turut menjadi faktor yang menyebabkan hambatan-hambatan dalam pelaksanaan alih teknologi dalam kaitan pengaturan lisensi paten. Menurut Direktorat Jenderal Hak Kekayaan Intelektual, untuk memenuhi kewajiban penanaman modal di Indonesia, investor asing wajib melakukan alih teknologi melalui perjanjian lisensi. Sedangkan menurut Badan Koordinasi Penanaman Modal, proses alih teknologi didasarkan pada Pasal 10 ayat (3) Undang-Undang No. 25 Tahun 2007 tentang Penanaman Modal, dimana perusahaan penanaman modal wajib meningkatkan kompetensi tenaga kerja warga negara Indonesia melalui pelatihan kerja sesuai dengan ketentuan peraturan perundang-undangan

Selain sarana-sarana tersebut, United Nations Centre on Transnational Corporations (UNCTC) menyebutkan setidaknya terdapat 9 (sembilan) sarana untuk melakukan alih teknologi antara lain yaitu : foreign direct investment, joint ventures, licensing, franchising, management contracts, marketing contracts, technical service contracts, turn key contracts, dan international sub-contracting (UNCTC 1987). Hal yang dapat disimpulkan adalah bahwa dengan kata lain, sarana pengalihan teknologi pada dasarnya dapat melalui penanaman modal langsung (direct investment) dan melalui lisensi.

\section{d. Upaya Pemerintah dan Konsultan Hak Kekayaan Intelektual}

Pemerintah pada dasarnya merupakan regulator. Oleh karena itu, pemerintah dalam menciptakan kemandirian perekonomian nasional yang berbasis ilmu pengetahuan dan teknologi berupaya menyiapkan regulasi-regulasi yang dibutuhkan guna menunjang alih teknologi dan lisensi paten. Setidaknya terdapat 3 (tiga) undang-undang yang dominan mengaturnya antara lain pertama, Undang-Undang No. 14 Tahun 2001 tentang Paten; kedua, Undang-Undang 25 Tahun 2007 tentang Penanaman Modal; dan ketiga, Undang-Undang No. 3 Tahun 2014 tentang
Perindustrian.

Lahirnya Undang-Undang Perindustrian yang baru, merupakan upaya pemerintah dalam mempercepat pelaksanaan alih teknologi di Indonesia. Pasal 39 Undang-Undang No. 3 Tahun 2014 tentang Perindustrian, menyebutkan antara lain bahwa :

1. Dalam keadaan tertentu, Pemerintah dapat melakukan pengadaan Teknologi Industri melalui proyek putar kunci.

2. Penyedia teknologi dalam proyek putar kunci wajib melakukan alih teknologi kepada pihak domestik.

3. Ketentuan lebih lanjut mengenai pengadaan Teknologi Industri melalui proyek putar kunci sebagaimana dimaksud pada ayat (1) diatur dengan Peraturan Presiden.

4. Penyedia teknologi dalam proyek putar kunci yang tidak melakukan alih teknologi sebagaimana dimaksud pada ayat (2) dikenai sanksi administratif berupa :

a. peringatan tertulis;

b. denda administratif; dan/atau

c. penghentian sementara.

5. Ketentuan mengenai tata cara pengenaan sanksi administratif dan besaran denda administratif sebagaimana dimaksud pada ayat (4) diatur dalam Peraturan Pemerintah.

Proyek putar kunci atau yang lebih dikenal dengan istilah turnkey project merupakan salah satu mekanisme alih teknologi berupa pengadaan teknologi dengan cara membeli suatu proyek teknologi secara lengkap yang dimulai dari pengkajian (asesmen), rancang bangun dan perekayasaan, implementasi (pengoperasian), dan penyerahan dalam kondisi siap digunakan. Ketika Indonesia dalam keadaan mendesak, Pemerintah dapat mewajibkan bagi penyedia teknologi proyek putar kunci untuk melakukan alih teknologi kepada pihak dalam negeri. Pemerintah dapat mengadakan perjanjian pengadaan teknologi melalui proyek putar kunci ini, ketika di dalam negeri terjadi keadaan dimana kebutuhan pembangunan industri sangat mendesak namun teknologi yang ada belum dapat dikuasai baik secara desain, perekayasaan, pengadaan, dan pembangunan (engineering, procurement, construction). 
Keadaan mendesak seperti inilah yang kemudian menjadi alasan bagi pemerintah untuk mewajibkan bagi penyedia teknologi proyek putar kunci untuk melakukan alih teknologi kepada pihak dalam negeri.

Peran konsultan Hak Kekayaan Intelektual dalam pelaksanaan alih teknologi melalui perjanjian lisensi paten sangatlah dibutuhkan. Peran konsultan Hak Kekayaan Intelektual yang mewakili para pemegang paten di dalam negeri dan di luar negeri adalah dengan melakukan sosialisasi kepada masyarakat akan manfaat perlindungan paten sehingga jumlah pemohon paten menjadi meningkat serta turut pula mensosialisasikan terkait penegakan hukumnya. Diharapkan, peran konsultan Hak Kekayaan Intelektual tidak hanya lebih diorientasikan pada pendaftaran Hak Kekayaan Intelektual saja tetapi juga pada pencatatan lisensi pada Direktorat Jenderal.

\section{e. Urgensi Pengaturan Khusus tentang Lisensi Paten di Bidang Alih Teknologi pada Perusahaan Joint Venture}

Seperti yang telah dijelaskan sebelumnya, bahwa meskipun United Nations Centre on Transnational Corporations (UNCTC) telah membagi 9 (sembilan) cara atau sarana dalam rangka melakukan alih teknologi, namun secara garis besar sarana alih teknologi dapat dilakukan melalui penanaman modal secara langsung dan melalui perjanjian lisensi. Sehingga alangkah baiknya apabila kedua sarana tersebut dapat diselenggarakan secara berimbang.

Hasil penelitian Jean Raymond Homere yang ditulis oleh Purba (2011) mengungkapkan bahwa pada negara-negara berkembang seperti di daerah Sub Sahara dan Eropa Timur yang sudah memiliki sistem Hak Kekayaan Intelektual yang ketat, tetapi mereka hanya mengundang sedikit investasi asing, sehingga potensi alih teknologinya pun juga rendah. Hal sebaliknya terjadi pada negara Cina, Brazil, Argentina dan Thailand yang berhasil memikat banyak penanaman modal asing tetapi sistem Hak Kekayaan Intelektualnya masih lemah.

Sementara hasil penelitian J. Luke Wigley yang ditulis oleh Purba (2011) men- gungkapkan bahwa investasi perusahaan-perusahaan transnasional di Thailand atau Indonesia sebagai negara-negara berkembang bukan karena mereka mau memperkenalkan teknologi baru, tetapi semata-mata untuk mengejar buruh murah, wilayah yang tidak ketat aturan lingkungannya dan keuntungan lain yang tidak berurusan langsung dengan kepentingan pembangunan di negara-negara berkembang itu.

Sebagai gambaran, bagaimana cara Pemerintah Cina dalam menyelenggarakan perlindungan paten dan alih teknologi di negaranya, selain memasukkan ketentuan untuk kepentingan negara dalam Undang-Undang Hak Kekayaan Intelektual, Pemerintah Cina juga memberikan syarat kepada pemodal asing yang menanamkan modalnya di negara Cina untuk melakukan alih teknologi. Bagi pemodal asing yang memenuhi syarat tersebut dan dapat diterapkan sampai pada tingkat dasar, akan diberikan insentif dan fasilitas yang sangat bagus.

Cina juga memberikan toleransi terhadap tindakan pelanggaran Hak Kekayaan Intelektual khususnya paten sepanjang dianggap akan mampu mendorong warga negara atau perusahaan nasional menguasai dan mengembangkan ilmu pengetahuan dan teknologi. Pada posisi ini, Pemerintah Cina menerapkan politik dua muka, yakni di satu sisi memberikan toleransi yang cukup kepada pelanggar Hak Kekayaan Intelektual namun di sisi lain melakukan penindakan terhadap pelaku pelanggar Hak Kekayaan Intelektual (Candra Irawan yang dikutip oleh BPHN dalam Naskah Akademik Undang-Undang Paten atas perubahan Undang-Undang No. 14 Tahun 2001 tentang Paten).

Toleransi yang diberikan oleh Pemerintah Cina terhadap pelanggaran Hak Kekayaan Intelektual tentunya mendapat sorotan tajam dari dunia. Hal ini karena daya kreasi yang mereka kembangkan bukan sematamata untuk menciptakan barang atau invensi baru, tetapi dengan meniru karya orang lain. Mereka hanya melakukan perubahan sedikit atau memakai bahan baku lain yang sesuai dengan aslinya, dengan demikian mereka tidak bisa dituntut sebagai pencuri Hak Kekayaan Intelektual yang dimiliki oleh orang 
lain. Mereka menyadari bahwa alih teknologi bukanlah sesuatu yang murah dan mudah, sehingga dengan alasan untuk pengembangan ilmu pengetahuan dan teknologi, tindakan pelanggaran terhadap Hak Kekayaan Intelektual dianggap sesuatu yang wajar oleh Pemerintah Cina.

Sekalipun Cina telah mengenal Undang-Undang Hak Kekayaan Intelektual semenjak tahun 1840-an, tetapi Pemerintah Cina tidak terburu-buru menjadi anggota World Trade Organization (WTO) dan/atau meratifikasi TRIPs Agreement, sebelum menyiapkan diri dan dipandang mampu bersaing dengan Hak Kekayaan Intelektual yang dimiliki oleh negara-negara maju. Pemerintah Cina menyiapkan dirinya dengan cara meningkatkan penguasaan terhadap ilmu pengetahuan dan teknologi serta kemandirian ekonomi. Sehingga, dengan sendirinya pendaftaran paten lebih banyak berasal dari pendaftar dalam negeri dibandingkan dengan pendaftar dari luar negeri.

Sudah saatnya Indonesia mulai berbenah dengan melakukan manuver perubahan baik dari segi peraturan perundang-undangannya maupun praktik penyelenggaraan paten dan alih teknologinya terutama melalui kegiatan joint venture. Menganalisis mekanisme alih teknologi yang terdapat pada Pasal 10 ayat (3) Undang-Undang No. 25 Tahun 2007 tentang Penanaman Modal dan Pasal 17 Undang-Undang No. 14 Tahun 2001 tentang Paten, maka akan didapatkan bahwa kegiatan joint venture yang diharapkan terjadi alih teknologi, pada praktiknya menimbulkan keuntungan dan kerugian bagi Indonesia. Keuntungan pelaksanaan joint venture yang diperoleh oleh Indonesia sebagai berikut :

1. Mitra lokal atau perusahaan dalam negeri, mendapatkan bantuan pendanaan dengan memanfaatkan modal asing.

2. Mitra lokal atau perusahaan dalam negeri, dapat memanfaatkan kemampuan manajemen asing yang penuh dengan pengalaman.

3. Mitra lokal atau perusahaan dalam negeri, dapat meningkatkan kemampuan karyawan dalam negeri dengan adanya training (keterampilan) yang diberikan oleh mitra asing atau perusahaan asing- nya.

4. Mitra lokal atau perusahaan dalam negeri, dapat menerima alih teknologi dari mitra asing atau perusahaan asingnya.

Kerugian pelaksanaan joint venture yang diperoleh oleh Indonesia sebagai berikut :

1. Manajemen tidak dapat dikuasai secara penuh oleh mitra lokal atau perusahaan dalam negeri karena harus dibagi dengan pihak asing sebagai pihak yang lebih mempunyai kemampuan.

2. Training dan manajemen yang diberikan oleh mitra asing atau perusahaan asingnya belum tentu diberikan secara optimal dalam batas-batas kemampuan yang memadai untuk standar asing.

3. Alih teknologi dari mitra asing atau perusahaan asingnya mungkin dilakukan dalam ukuran yang kurang optimal. Selain itu, hasil-hasil dari penelitian dan pengembangan tidak akan seluruhnya diberikan dalam kegiatan joint venture.

Selain merenungkan keuntungan dan kerugian kegiatan joint venture dalam keterkaitannya dengan alih teknologi, Pemerintah Indonesia juga tidak perlu mengikuti cara Pemerintah Cina dengan memberikan toleransi untuk menjadi 'pencuri' Hak Kekayaan Intelektual dengan alasan demi melejitkan ilmu pengetahuan dan teknologi. Meskipun sebenarnya Pemerintah Indonesia dapat mengikuti cara Pemerintah Cina tersebut, yang didasarkan pada Pasal 16 ayat (3) UndangUndang No 14 Tahun 2001 tentang Paten mengenai fungsi sosial paten dimana hak eksklusif dapat dikecualikan apabila pemakaian paten untuk kepentingan pendidikan, penelitian, percobaan, atau analisis sepanjang tidak merugikan kepentingan yang wajar dari pemegang paten. Namun ketentuan mengenai fungsi sosial paten ini tidak dapat diterapkan secara semena-mena, karena tetap dibatasi oleh pengakuan hak moral pada paten yang diatur dalam Pasal 68 UndangUndang No 14 Tahun 2001 tentang Paten, dimana peralihan pemilikan paten tidak menghapus hak inventor untuk tetap dicantumkan nama dan identitas lainnya dalam paten yang bersangkutan.

Hal yang perlu dilakukan oleh Peme- 
rintah Indonesia adalah dengan membentuk pengaturan paten dan alih teknologi yang tepat dan kuat, di samping terus memberikan kebijakan berupa insentif dan kemudahan fasilitas untuk meningkatkan semangat peneliti untuk terus menciptakan daya kreasi dan inovasi, maka dengan sendirinya ilmu pengetahuan dan teknologi akan berkembang dengan pesat, yang ditandai dengan pendaftaran paten lebih banyak dilakukan oleh pendaftar dalam negeri daripada luar negeri.

Oleh karenanya, dalam hal ini perlu direnungkan kembali terhadap latar belakang, maksud dan tujuan yang termuat dalam Undang-Undang Paten yang ada saat ini. Selain memberikan perlindungan hukum kepada para investor atau penemu atas hasil karya, inovasi dan daya kreasinya dalam sebuah invensi, tujuan diundangkannya Undang-Undang Paten adalah untuk meningkatkan dan mempercepat penguasaan ilmu dan teknologi yang dibutuhkan dalam bidang industri oleh bangsa Indonesia.

Melalui sistem Hak Kekayaan Intelektual yakni sistem paten yang tepat, diharapkan industri beserta teknologinya dapat berkembang dengan pesat pula. Pada praktiknya, proses alih teknologi di Indonesia masih terkendala oleh belum adanya suatu pengaturan khusus mengenai alih teknologi, yakni Peraturan Pemerintah tentang lisensi paten yang telah diamanatkan dalam Undang-Undang No. 14 Tahun 2001 tentang Paten.

Sumantoro (1993) dalam bukunya Masalah Pengaturan Alih Teknologi mengungkapkan bahwa untuk membentuk suatu sistem Hak Kekayaan Intelektual yang kuat, setidaknya mengandung 3 (tiga) unsur yakni :

Pejabat yang berwenang di negara penerima teknologi, memiliki kualitas dan mampu melaksanakan peraturan perundangundangan atau kebijaksanaan di bidang tersebut secara efektif.

Pengaturan yang ada di negara penerima teknologi, perlu fleksibel sehingga memungkinkan mengadakan perubahan atau pembahasan dengan cara cepat.

Pihak pemberi teknologi asing harus bersedia mengisi kontrak alih teknologi berdasar peraturan perundang-undangan yang ada di negara penerima teknologi.
Berbarengan dengan pernyataan Sumantoro tersebut, maka sesuai pula dengan teori Lawrence M. Friedman bahwa sistem hukum merupakan suatu kesatuan hukum yang tersusun atas tiga unsur yakni struktur, substansi, dan budaya hukum. Membentuk sistem hukum alih teknologi yang kuat dibutuhkan ketiga unsur tersebut untuk bekerja secara bersama-sama.

Unsur yang pertama adalah struktur hukum (legal structure) dalam proses alih teknologi melalui perjanjian lisensi. Pada praktiknya, pihak-pihak atau instansi-instansi terkait seperti Direktorat Paten, Direktorat Jenderal Hak Kekayaan Intelektual tidak mengetahui berapa jumlah perusahaan yang mempunyai perjanjian lisensi paten. Selain itu, mereka juga tidak merasa mempunyai wewenang untuk menegakkan ketentuan Pasal 72 Undang-Undang No. 14 Tahun 2001 tentang Paten, karena tidak adanya landasan hukum untuk bertindak. Landasan hukum yang dimaksudkan adalah Peraturan Pemerintah tentang lisensi paten. Melalui Peraturan Pemerintah tentang lisensi paten, pemerintah yang diwakili oleh Direktorat Paten mampu menjalankan tugasnya sebagai pengawas perjanjian lisensi paten, agar kedudukan antara licensor dan licensee berada pada posisi seimbang dan kewajiban alih teknologi benar-benar terlaksana.

Oleh karenanya, Direktorat Jenderal Hak Kekayaan Intelektual yang dalam hal ini diwakili oleh Direktorat Paten selaku instansi yang berwenang untuk melakukan pencatatan perjanjian lisensi paten yang dimulai sejak pemeriksaan terhadap permohonan pencatatan perjanjian lisensi paten hingga menerbitkan surat pencatatan perjanjian lisensi paten tersebut, belum dapat menjalankan kewajibannya. Di sisi lain, jika perjanjian lisensi tidak dicatatkan maka perjanjian lisensi tersebut tidak mempunyai akibat hukum terhadap pihak ketiga. Dengan kata lain, jika perjanjian lisensi tersebut dicatatkan dan di kemudian hari terjadi sengketa yang melibatkan pihak ketiga, maka Pengadilan sebagai instansi yang berwenang menangani sengketa perjanjian lisensi paten tersebut. Selain kedua instansi tersebut, Kementerian Perindustrian, Kementerian Hukum dan Hak Asasi 
Manusia dan Badan Koordinasi Penanaman Modal juga tidak dapat mendesak perusahaan penanaman modal asing untuk melakukan alih teknologi melalui perjanjian lisensi paten ini, jika Peraturan Pemerintah tentang lisensi paten tersebut belum diundangkan.

Unsur yang kedua adalah substansi hukum (legal substance), sebenarnya pengaturan mengenai kewajiban alih teknologi telah banyak diatur dalam sejumlah peraturan perundang-undangan. Meskipun di dalam Undang-Undang No. 14 Tahun 2001 tentang Paten tidak mengatur mengenai sanksi apabila tidak melakukan alih teknologi selain yang diatur di dalam Pasal 72 ayat (2) dimana apabila perjanjian lisensi paten tersebut tidak dicatatkan pada Direktorat Jenderal maka tidak mempunyai akibat hukum bagi pihak ketiga, kini di dalam Pasal 39 Undang-Undang No. 3 Tahun 2014 tentang Perindustrian telah diatur sedemikian rupa agar dapat memaksa adanya alih teknologi, dimana disebutkan bahwa penyedia teknologi dalam proyek putar kunci yang tidak melakukan alih teknologi dikenai sanksi administratif berupa peringatan tertulis; denda administratif; dan/ atau penghentian sementara. Pemerintah dapat menjalankan fungsi eksekutifnya kepada para penyedia teknologi pada proyek putar kunci yang tidak melakukan alih teknologi dengan dikenai sanksi administratif berupa peringatan tertulis, denda administratif, dan/ atau penghentian sementara. Adanya sanksi administratif ini bertujuan agar penyedia teknologi pada proyek putar kunci benar-benar melakukan alih teknologi kepada pihak nasional atau dalam negeri.

Pembahasan alih teknologi melalui perjanjian lisensi paten difokuskan pada pengaturan tentang sarana atau cara melakukan alih teknologi melalui lisensi paten. Sehingga bisa saja dalam hal tidak dicatatkannya perjanjian lisensi paten tentang alih teknologi, dikenai sanksi administratif berupa peringatan tertulis; denda administratif; dan/atau penghentian sementara. Tujuannya agar para pihak tidak memanfaatkan asas kebebasan berkontrak untuk tidak mendaftarkan perjanjian lisensi patennya meskipun di dalam Undang-Undang Paten telah menegaskan bahwa perjanjian lisensi yang tidak dicatat- kan maka tidak mempunyai akibat hukum bagi pihak ketiga.

Permasalahannya adalah sudah 13 (tiga belas) tahun sejak Undang-Undang Paten diundangkan sampai pada tahun 2014 ini, aturan penjelas berupa Peraturan Pemerintah seperti yang diamanatkan dalam Pasal 73 Undang-Undang No. 14 Tahun 2001 tentang Paten belum ada. Kalaupun sudah ada, masih dalam tahap Draf Rancangan Peraturan Pemerintah yang masih berhenti di Kementerian Hukum dan Hak Asasi Manusia Republik Indonesia. Padahal dengan adanya Peraturan Pemerintah tentang lisensi paten tersebut akan lebih mempertajam lagi kewajiban untuk melakukan alih teknologi bagi para pihak. Namun lagi-lagi, bangsa Indonesia harus menunggu lahirnya landasan hukum mengenai alih teknologi melalui perjanjian lisensi paten tersebut, karena ketentuan tentang pencatatan perjanjian lisensi paten akan diatur lebih lanjut dalam Peraturan Menteri.

Kebijakan alih teknologi pada dasarnya dipengaruhi pula oleh produk peraturan perundang-undangan tentang teknologi dan alih teknologi yang dimiliki oleh negara tersebut. Susilowati (2005) berpendapat bahwa hal ini tidak terlepas dari kemauan politik (political will) Pemerintah yang sangat kuat, khususnya bagi mereka yang berpendapat bahwa kebijakan pengembangan teknologi dan alih teknologi merupakan landasan untuk kemajuan ekonomi suatu negara. Direktorat Jenderal Hak Kekayaan Intelektual yang diwakili oleh Direktorat Paten telah berupaya mendorong dan menjadi pelopor terbentuknya Peraturan Pemerintah tentang Lisensi Paten dan Lisensi Wajib, dengan isi dari substansi draf Peraturan Pemerintah tersebut sudah menyeimbangkan bargaining position pemerintah dan masyarakat bisnis. Kini tinggallah kemauan politik (political will) Kementerian Hukum dan Hak Asasi Manusia Republik Indonesia untuk mengajukan draf Peraturan Pemerintah ini kepada Presiden melalui Sekretaris Negara. Berikut adalah tabel perbandingan kebijakan alih teknologi dan kontrak alih teknologi di negara-negara Asia (Susilowati 2005) :

Kiranya Indonesia perlu belajar dari negara-negara lain di Asia untuk mewujudkan 
Tabel 2. Perbandingan kebijakan alih teknologi dan kontrak alih teknologi di negara-negara Asia

\begin{tabular}{|c|c|c|c|}
\hline No. & Negara & Kebijakan Alih Teknologi & Kontrak Alih Teknologi \\
\hline 1. & Malaysia & $\begin{array}{l}\text { Teknologi sebagai faktor yang sangat } \\
\text { vital pada pembangunan sektor in- } \\
\text { dustri, dilakukan melalui kebijakan } \\
\text { ekonomi baru yang diberikan pada } \\
\text { sektor swasta } \\
\text { Undang-undang untuk menjalankan } \\
\text { industri: } \\
\text { Investment Incentive Act (1968) } \\
\text { Industrial Coordination Act (1975) }\end{array}$ & $\begin{array}{l}\text { Diuraikan secara rinci tentang teknolo- } \\
\text { gi yang diperjanjikan. } \\
\text { Adanya kemudahan dari pemilik } \\
\text { teknologi, mencakup informasi muta- } \\
\text { hir. } \\
\text { Royalty berupa : fixed lumpsum fee } \\
\text { atau running royalty. } \\
\text { Periode perpanjangan ditentukan } 5 \text { ta- } \\
\text { hun, harus sepengetahuan pemerintah. } \\
\text { Paten yang digunakan sesudah habis } \\
\text { masa berlaku adalah milik umum. }\end{array}$ \\
\hline 2. & India & $\begin{array}{l}\text { Teknologi perlu dikembangkan } \\
\text { untuk dapat swa sembada dengan } \\
\text { memanfaatkan sumber daya nasi- } \\
\text { onal. Tujuan untuk menyediakan la- } \\
\text { pangan pekerjaan mengembangkan } \\
\text { teknologi, meningkatkan produksi, } \\
\text { memanfaatkan kemampuan untuk } \\
\text { berkompetisi. } \\
\text { Pemerintah menunjang segala usaha } \\
\text { pengembangan teknologi, diben- } \\
\text { tuk mekanisme pengawasan untuk } \\
\text { mengamankan kepentingan nasional } \\
\text { yang tunduk pada perlindungan } \\
\text { internasional yaitu Peraturan Hak } \\
\text { Milik Industri }\end{array}$ & $\begin{array}{l}\text { Kontrak PMA dengan pengawasan } \\
\text { pemerintah. } \\
\text { Kontrak harus diawali dengan infor- } \\
\text { masi teknologi yang cukup jelas dalam } \\
\text { rangka menentukan pilihan teknologi } \\
\text { tepat guna. } \\
\text { Upaya peningkatan produk melalui } \\
\text { kontrak lisensi paten, pemerintah ikut } \\
\text { campur. } \\
\text { Pemerintah menerapkan sistem kon- } \\
\text { trak alih teknologi dan memberikan } \\
\text { pengawasan pada bidang monitoring, } \\
\text { penilaian dan bimbingan teknologi, } \\
\text { perolehan, penyerapan, pemanfaatan } \\
\text { dan memperhatikan kepentingan pri- } \\
\text { oritas nasional. } \\
\text { Diatur dengan kebijakan teknologi } \\
\text { sesuai dengan pencapaian tujuan } \\
\text { teknologi secara menyeluruh. }\end{array}$ \\
\hline 3. & Korea & $\begin{array}{l}\text { Kebijakan tentang perdagangan } \\
\text { diatur pada The Korean Comercial } \\
\text { Code dan tentang teknologi diatur } \\
\text { pada Foreign Capital Inducement } \\
\text { Law (FCIL), yang bertujuan untuk } \\
\text { meningkatkan industri dan laju } \\
\text { perkembangan ekonomi. } \\
\text { Memprioritaskan research \& devel- } \\
\text { opment (R \& D). } \\
\text { Dukungan pemerintah sangat besar } \\
\text { baik di bidang finansial maupun } \\
\text { institusional. } \\
\text { Mengusahakan terciptanya iklim } \\
\text { yang menunjang investasi asing. } \\
\text { Sumber daya manusia diutamakan } \\
\text { dalam rangka memanfaatkan } \\
\text { teknologi asing. }\end{array}$ & $\begin{array}{l}\text { Kontrak lisensi diawasi secara ketat } \\
\text { oleh pemerintah. } \\
\text { Klausula-klausula kontrak dari pemilik } \\
\text { teknologi sangat membebani penerima } \\
\text { teknologi akan tetapi dapat digunakan } \\
\text { sebagai perangsang untuk segera } \\
\text { mampu menyerap dan menguasai } \\
\text { prinsip teknologi impor. } \\
\text { Klausula kontrak cenderung lebih } \\
\text { panjang, alasannya (1) teknologi yang } \\
\text { diimpor adalah jenis teknologi kunci } \\
\text { yang butuh poses penyesuaian lebih } \\
\text { lama; (2) kemampuan untuk bernego- } \\
\text { siasi; (3) impor teknologi cenderung } \\
\text { bersifat memaksakan kehendak dari } \\
\text { pemilik teknologi. } \\
\text { Syarat kontrak teknologi dari pemi- } \\
\text { lik teknologi lebih diperketat setelah } \\
\text { sumber daya manusianya dipersiapkan } \\
\text { secara matang. } \\
\text { Dari survey yang dilakukan pada } 300 \\
\text { perusahaan domestik, telah berhasil } \\
\text { mengembangkan kualitas produksinya. } \\
60 \% \text { dari perusahaan tersebut telah } \\
\text { mampu bersaing di pasar internasional. }\end{array}$ \\
\hline
\end{tabular}




\begin{tabular}{|c|c|c|c|}
\hline 4. & Thailand & $\begin{array}{l}\text { Kebijaksanaan PMA diatur pada (1) } \\
\text { The Alien Business Law Decree281; } \\
\text { (2) Investment Promotion Act.B.E. } \\
2520 \\
\text { Perusahaan bebas membuat kontrak } \\
\text { untuk memperoleh teknologi. } \\
\text { Meningkatkan posisi tawar pihak } \\
\text { domestik, dilakukan dengan cara } \\
\text { (1) pembatasan bisnis dari pemi- } \\
\text { lik teknologi tidak diberlakukan; } \\
\text { (2) membentuk unit lawyer untuk } \\
\text { mendampingi pembuatan kontrak; } \\
\text { (3) pemerintah menyediakan infor- } \\
\text { masi teknologi } \\
\text { Kebijakan teknologi diawasi melalui } \\
\text { Bank of Thailand } \\
\text { Wewenang Bank of Thailand berkai- } \\
\text { tan dengan pembayaran devisa } \\
\text { sehingga terdaftar perusahaan-pe- } \\
\text { rusahaan yang mencantumkan pen- } \\
\text { giriman biaya atau upah teknologi } \\
\text { pada pemilik teknologi setiap tahun. }\end{array}$ & $\begin{array}{l}\text { Kontrak lisensi paten diatur secara } \\
\text { kontraktual } \\
\text { Bebas untuk mengadakan kontrak } \\
\text { lisensi dengan negara manapun dan } \\
\text { tidak diawasi oleh pemerintah } \\
\text { Jangka waktu kontrak melebihi } 10 \\
\text { tahun sehingga biaya teknologi sangat } \\
\text { tinggi. } \\
\text { Pada kontrak ditentukan secara ketat } \\
\text { tentang pembatasan pada pemilik } \\
\text { teknologi, di antaranya (1) larangan } \\
\text { ekspor total atau hanya diberi we- } \\
\text { wenang pada pasar tertentu saja; (2) } \\
\text { penerima teknologi harus membeli } \\
\text { bahan baku dari pemilik teknologi; } \\
\text { (3) pemilik teknologi berusaha untuk } \\
\text { selalu mengontrol volume, arah dan } \\
\text { saluran perdagangan komoditi dan } \\
\text { secara efektif menciptakan jaringan } \\
\text { pemasaran sendiri; (4) pembatasan } \\
\text { terhadap alih teknologi; (5) larangan } \\
\text { penggunaan know how; (6) produksi } \\
\text { dan penjualan berhenti setelah kontrak } \\
\text { selesai; (7) dilarang mengalihkan } \\
\text { teknologi secara sublisensi pada pihak } \\
\text { ketiga. }\end{array}$ \\
\hline 5. & Indonesia & $\begin{array}{l}\text { Kebijakan teknologi diatur di dalam } \\
\text { UU PMA, UU PMDN, UU Perindus- } \\
\text { trian, dan UU Paten. } \\
\text { Khusus tentang teknologi dan alih } \\
\text { teknologi belum ada pengaturan } \\
\text { secara formal. } \\
\text { Adanya pembatasan yang sangat } \\
\text { ketat oleh licensor atas teknologi } \\
\text { yang digunakan oleh licensee. } \\
\text { Pada kontrak yang diadakan, pihak } \\
\text { licensee lebih menitik beratkan pada } \\
\text { kebutuhan teknologi sedangkan } \\
\text { pada pelaksanaan kontrak, licensor } \\
\text { mempunyai kekuatan dan kekua- } \\
\text { saan pada bisnis yang dominan. } \\
\text { Pemerintah harus mengawasi secara } \\
\text { ketat kontrak teknologi melalui } \\
\text { kebijakan-kebijakan untuk lebih me- } \\
\text { nyeimbangkan keuntungan antara } \\
\text { pemilik dan penerima teknologi. } \\
\text { Meninjau kembali UU PMA dan } \\
\text { PMDN dengan Pasal-Pasal yang } \\
\text { lebih produktif dan prospektif bagi } \\
\text { pengembangan teknologi Indonesia. }\end{array}$ & $\begin{array}{l}\text { Kontrak dibuat atas dasar Pasal } \\
1338,1339,1320 \text { KUH Perdata dan } \\
\text { Undang-Undang No. } 14 \text { Tahun } 2001 \\
\text { tentang Paten. } \\
\text { Kontrak alih teknologi dibuat antara li- } \\
\text { censor dan licensee tanpa pengawasan } \\
\text { pihak pemerintah, } \\
\text { Kontrak dibuat atas dasar perancangan } \\
\text { kontrak sepihak oleh licensor. } \\
\text { Dicantumkan hak dan kewajiban } \\
\text { masing-masing. } \\
\text { Kontrak meliputi jaminan yang diberi- } \\
\text { kan oleh pemilik teknologi. } \\
\text { Licensee dapat menerima hak untuk } \\
\text { memproduksi, memakai merek da- } \\
\text { gang, dan memasarkan produk kecuali } \\
\text { diperjanjikan lain. } \\
\text { Kontrak lisensi harus didaftarkan pada } \\
\text { Dirjen HKI, tetapi belum ada aturan } \\
\text { pelaksanaannya. Sehingga sampai saat } \\
\text { ini tidak ada pengawasan dari pemer- } \\
\text { intah. } \\
\text { Mengingat sangat pentingnya penga- } \\
\text { wasan pemerintah pada kontrak alih } \\
\text { teknologi maka perlu segera diatur } \\
\text { tentang aturan pelaksanaanya. } \\
\text { Alasan utama karena pemerintah } \\
\text { pemegang kunci keberhasilan alih } \\
\text { teknologi di samping kemauan ma- } \\
\text { syarakat untuk meningkatkan sumber } \\
\text { daya yang dimiliki, baik sumber daya } \\
\text { alam maupun sumber daya manu- } \\
\text { sianya. }\end{array}$ \\
\hline
\end{tabular}


kemandirian perekonomian yang bersumber dari ilmu pengetahuan dan teknologi. Negara-negara tersebut sangat ketat dalam mengatur teknologi dan alih teknologi yang masuk ke negaranya, karena pemerintah turut mengawasi perjanjian lisensi dan mereka telah mempunyai undang-undang khusus yang mengatur teknologi dan alih teknologi. Hal inilah yang belum terdapat di Indonesia, maka melalui sistem Hak Kekayaan Intelektual yakni sistem paten yang tepat, diharapkan industri beserta teknologi di Indonesia dapat berkembang dengan pesat pula.

Terakhir adalah unsur budaya hukum atau legal culture. Mengenai budaya hukum para pihak dalam perusahaan penanaman modal asing berdasarkan hasil penelitian Suteki, partner nasional pada beberapa perusahaan yang telah diteliti oleh Suteki tidak pernah mempermasalahkan apakah paten yang dilisensikan tersebut masih berlaku ataukah tidak. Beberapa perusahaan mempunyai persepsi yang sama terhadap masa berlakunya lisensi paten. Pada akhirnya, jangka waktu perjanjian lisensi dapat berlangsung selama 10 tahun atau 20 tahun dan dapat pula dilakukan adendum sesuai kesepakatan para pihak. Sehingga dapat disimpulkan bahwa persepsi para pihak dalam perusahaan penanaman modal asing khususnya partner nasional mengenai jangka waktu perjanjian lisensi paten, bertentangan dengan ketentuan undang-undang.

Selain itu, persepsi para pihak dalam perusahaan penanaman modal asing mengenai asas kebebasan berkontrak dalam membuat perjanjian lisensi paten, pada akhirnya terdapat kemungkinan bahwa perjanjian lisensi paten tersebut tidak didaftarkan pada Direktorat Jenderal. Tidak hanya itu, licensor dan licensee dapat mencantumkan klausula yang masih dapat mengikat pihak ketiga yakni apabila terjadi sengketa dengan pihak ketiga maka dapat diselesaikan sesuai dengan kesepakatan yang telah dibuat oleh licensor dan licensee. Pada akhirnya, ketentuan dalam Pasal 72 ayat (2) Undang-Undang No. 14 Tahun 2001 tentang Paten berada dalam posisi yang lemah dalam pandangan licensor dan licensee.

Oleh karenanya, diperlukan pemba- tasan terhadap asas kebebasan berkontrak. Asas itikad baik harus diterapkan pula dalam pembuatan dan pelaksanaan perjanjian lisensi paten, sebagaimana yang ditentukan oleh Pasal 1338 ayat (3) KUH Perdata, dengan tujuan agar bargaining position licensor dan licensee seimbang dan tidak bertentangan dengan peraturan perundang-undangan yang berlaku. Pemerintah pun dapat mengawasi perjanjian lisensi paten ini, setidaknya melalui substansi hukum yang ada nantinya, mengatur mengenai sanksi tegas lainnya apabila perjanjian lisensi paten tersebut tidak tercatat seperti sanksi administratif berupa peringatan tertulis; denda administratif; dan/ atau penghentian sementara, seperti yang telah diterapkan pada Pasal 39 Undang-Undang No. 3 Tahun 2014 tentang Perindustrian.

Pentingnya budaya hukum untuk mendukung terciptanya sistem hukum yang kuat, sebagaimana yang disampaikan oleh Lawrence M Friedman bahwa substansi dan struktur saja tidak cukup untuk berjalannya suatu sistem hukum. Namun dalam konteks ini, budaya hukum dan struktur hukum tidak dapat terwujud sesuai cita-cita dan tujuan alih teknologi apabila substansi hukumnya saja belum ada. Ketika sistem hukum dengan ketiga unsurnya telah berjalan, maka dengan sendirinya fungsi hukum dalam Peraturan Pemerintah tentang Lisensi Paten dan Lisensi Wajib dapat terlihat. Fungsi hukum yang relevan dalam hal ini adalah fungsi hukum sebagai penyelesaian konflik, fungsi hukum sebagai kontrol sosial, dan fungsi hukum sebagai sarana untuk rekayasa sosial.

Fungsi hukum sebagai penyelesaian konflik dalam proses alih teknologi didasarkan pada perjanjian lisensi yang dibuat oleh para pihak. Perjanjian lisensi yang dicatatkan pada Direktorat Jenderal akan menimbulkan akibat hukum bagi pihak ketiga. Di sinilah fungsi hukum sebagai penyelesaian konflik, melalui proses litigasi, Pengadilan dapat berperan jika dibutuhkan oleh para pihak untuk menegakkan hukum apabila terdapat sengketa atau konflik dengan pihak ketiga.

Fungsi hukum sebagai kontrol sosial dalam proses alih teknologi melalui perjanjian lisensi didasarkan pada moral dengan 
mendasarkan pada kesepakatan, asas kebebasan berkontrak, dan asas itikad baik dari para pihak yang membuat perjanjian lisensi alih teknologi. Jika sebelum adanya pengaturan khusus tentang perjanjian lisensi dimungkinkan kesepakatan yang dibuat oleh para pihak berada pada posisi yang tidak seimbang, mengingat pihak licensor memiliki bargaining position yang kuat sebagai pemilik teknologi, namun keadaan ini tidak lagi terjadi ketika Peraturan Pemerintah tentang Lisensi Paten dan Lisensi Wajib diundangkan nantinya. Hal ini karena, dalam peraturan pemerintah tersebut telah memuat pembatasan-pembatasan yang lebih jelas mengenai perjanjian lisensi tidak boleh memuat ketentuan, baik langsung maupun tidak langsung yang dapat merugikan perekonomian Indonesia atau memuat pembatasan yang menghambat kemampuan bangsa Indonesia dalam menguasai dan mengembangkan teknologi pada umumnya dan yang berkaitan dengan invensi yang diberi Paten tersebut pada khususnya. Sehingga, licensor tidak lagi bisa berprinsip semata-mata hanya mengejar kepentingan ekonomi saja.

Fungsi hukum lainnya dalam proses alih teknologi adalah sebagai sarana untuk melakukan rekayasa sosial. Fungsi hukum ini melibatkan penggunaan peraturan-peraturan yang dibuat oleh pihak legislatif untuk menimbulkan akibat-akibat yang dilakukan oleh para pihak dalam perusahaan penanaman modal asing dan juga pemerintah. Peraturan Pemerintah tentang Lisensi Paten dan Lisensi Wajib dapat berfungsi sebagai alat rekayasa untuk merealisasikan alih teknologi melalui perjanjian lisensi.

Pembentukan Peraturan Pemerintah tentang Lisensi Paten dan Lisensi Wajib, berkaitan erat dengan politik pembentukan hukum pasca Amandemen Undang-Undang Dasar 1945. Bahkan menurut Hans Kelsen (2007:163 dalam artikel Darwin Botutihe) mengatakan pembentukan hukum adalah rangkaian awal dari penegakkan hukum yang sangat penting untuk diperhatikan. Pasal 20 ayat (1) Undang-Undang Dasar 1945 telah mengatur bahwa Dewan Perwakilan Rakyat (DPR) memegang kekuasaan untuk membentuk undang-undang. Memperhatikan
Pasal 20 Undang-Undang Dasar 1945 ini, pembentuk hukum di Indonesia dipegang oleh DPR. Hanya saja, kekuasaan DPR dalam membentuk hukum tidak dapat dikerjakan secara mandiri melainkan harus bersamasama dengan Presiden.

Sistem hukum dan fungsi hukum mengenai alih teknologi melalui perjanjian lisensi paten tidak akan berjalan jika legislatif tidak segera menjalankan kekuasaannya untuk membentuk hukum, padahal kemandirian perekonomian suatu bangsa ditunjang oleh aspek ilmu pengetahuan dan teknologi, penanaman modal langsung (direct investment) dan ketahanan sistem Hak Kekayaan Intelektual yang dimiliki oleh negara tersebut.

\section{Simpulan}

Dasar hukum alih teknologi melalui perjanjian lisensi paten diatur di dalam Pasal 69-73 Undang-Undang No. 14 Tahun 2001 tentang Paten, namun ketentuan ini masih belum sempurna dikarenakan belum adanya Peraturan Pemerintah tentang Lisensi Paten dan Lisensi Wajib seperti yang diamanahkan di dalam Pasal 73 UndangUndang No. 14 Tahun 2001 tentang Paten. Sehingga, selama tahun 2001 hingga tahun 2013, Direktorat Jenderal belum melakukan pencatatan terhadap perjanjian lisensi paten. Hal ini disebabkan pengaturan lebih detail terkait pencatatan lisensi paten seperti bentuk formulir, biaya pendaftaran, dan persyaratannya, diatur lebih detail pada Peraturan Pemerintah tentang Lisensi Paten dan Lisensi Wajib. Kebijakan alih teknologi pada dasarnya dipengaruhi oleh produk peraturan perundang-undangan tentang teknologi dan alih teknologi yang dimiliki oleh negara tersebut. Kiranya Indonesia perlu belajar dari negara-negara lain di Asia, negara-negara tersebut sangat ketat dalam mengatur teknologi dan alih teknologi yang masuk ke negaranya, karena Pemerintah turut mengawasi perjanjian lisensi dan mereka telah mempunyai undang-undang khusus yang mengatur teknologi dan alih teknologi, hal inilah yang belum terdapat di Indonesia. Melalui Peraturan Pemerintah tentang lisensi paten, Pemerintah mampu menjalankan tugasnya sebagai pen- 
gawas perjanjian lisensi paten, agar kedudukan antara licensor dan licensee berada pada posisi seimbang dan kewajiban alih teknologi benar-benar terlaksana.

\section{Ucapan Terima Kasih}

Terimakasih penulis sampaikan kepada Ibu Waspiah, S.H., M.H, yang telah memberikan masukan dalam proses penelitian. Demikian juga terimakasih, penulis sampaikan kepada bapak Saru Arifin, S.H., L.L.M, yang juga memberikan masukan dan kritik dalam penulisan artikel ini. Selain itu, penulis juga menyampaikan terimakasih kepada Dr. Sabartua Tampubolon, S.H., M.H., sebagai Responden di Kementerian Riset dan Teknologi Republik Indonesia. Terimakasih kepada Aris Ideanto, S.H., M.H., Responden di Direktorat Jenderal Hak Kekayaan Intelektual, Kementerian Hukum dan Hak Asasi Manusia Republik Indonesia, dan terakhir terimakasih juga penulis sampaikan kepada Gatot Subyargo Wijayadi S.H., M.H, Responden di Badan Koordinasi Penanaman Modal Republik Indonesia.

\section{Daftar Pustaka}

BPHN. Naskah Akademik Rancangan Undang-Undang tentang Paten atas Perubahan Undang-Undang
No. 14 Tahun 2001 tentang Paten

Hartono, S. 1974. Masalah-Masalah dalam Joint Venture antara Modal Asing dan Modal Indonesia. PT. Alumni. Bandung

Ilmar, A. 2006. Hukum Penanaman Modal di Indonesia. Kencana. Jakarta

Maulana, I.B. 1996. Lisensi Paten. Citra Aditya Bakti. Bandung

Purba, A.Z.U. 2011. Perjanjian TRIPs dan Beberapa Isu Strategis. PT. Alumni. Bandung

Soekanto, S. 1986. Pengantar Penelitian Hukum. UIPres. Jakarta

Suherman, A.M. 2004. Pengantar Perbandingan Sistem Hukum. PT. RajaGrafindo Persada. Jakarta

Sumantoro. 1984. Bunga Rampai Permasalahan Penanaman Modal dan Pasar Modal (Problems of Investment in Equities in Securities). Bina Cipta. Jakarta

Susilowati, E. 2007. Kontrak Alih Teknologi pada Industri Manufaktur. Genta Press. Yogyakarta

Suteki. 2013. Hukum dan Alih Teknologi (Sebuah Pergulatan Sosiologis). Thafa Media. Yogyakarta

Tampubolon, S. 2013. Politik Hukum Iptek di Indonesia. Kepel Press. Yogyakarta

UNCTC. 1987. Transnational Coorporations and Technology Transfer: Effects ad Policy Issues. United Nations. 